\title{
United States still too lenient on "faith healing" parents, say children's rights advocates
}

$\mathrm{T}$ wo parents in Oregon who refused to seek treatment for their infant daughter's tumour on religious grounds were recently sentenced to jail time, but advocates for children's medical rights remain concerned about the leniency the justice system shows to "faith healing" families in some areas of the United States.

Timothy Wyland, 44, and Rebecca Wyland, 23, of Oregon City were found guilty of criminal mistreatment for allowing their 18-month-old daughter's hemangioma, an abnormal proliferation of blood vessels, to grow into a golf ballsized tumour that covered one eye. They were sentenced to three months in jail on June 24. Rather than seek medical care for their daughter, the Wylands, members of the Followers of Christ Church, relied on prayer, oil anointment and the "laying on of hands."

Dr. Seth Asser, a Rhode Island pediatrician, argues that lawmakers and judges often fail to recognize the dangers of faith healing. "Children who have died in these cases suffer seizures, vomiting," he says. "Their deaths are agonizing, slow and extremely painful."

An investigation led by Asser published in Pediatrics found that between 1975 and 1995, 172 children died following faith healing, 140 from easily curable or treatable medical conditions (Pediatrics 1998;101:625-9). In one case, a two-year-old girl choked on a banana and showed signs of life for an hour before dying, while her parents and other adults simply prayed.

In the late 1970s and early 1980s, most states had faith healing exemptions in their child abuse and neglect laws. Nineteen states still allow religious defences for felony crimes against children.

Canada, by contrast, does not have religious exemptions to criminal charges such as neglect. However, while children of Jehovah's Witnesses have died as a result of parents' refusals

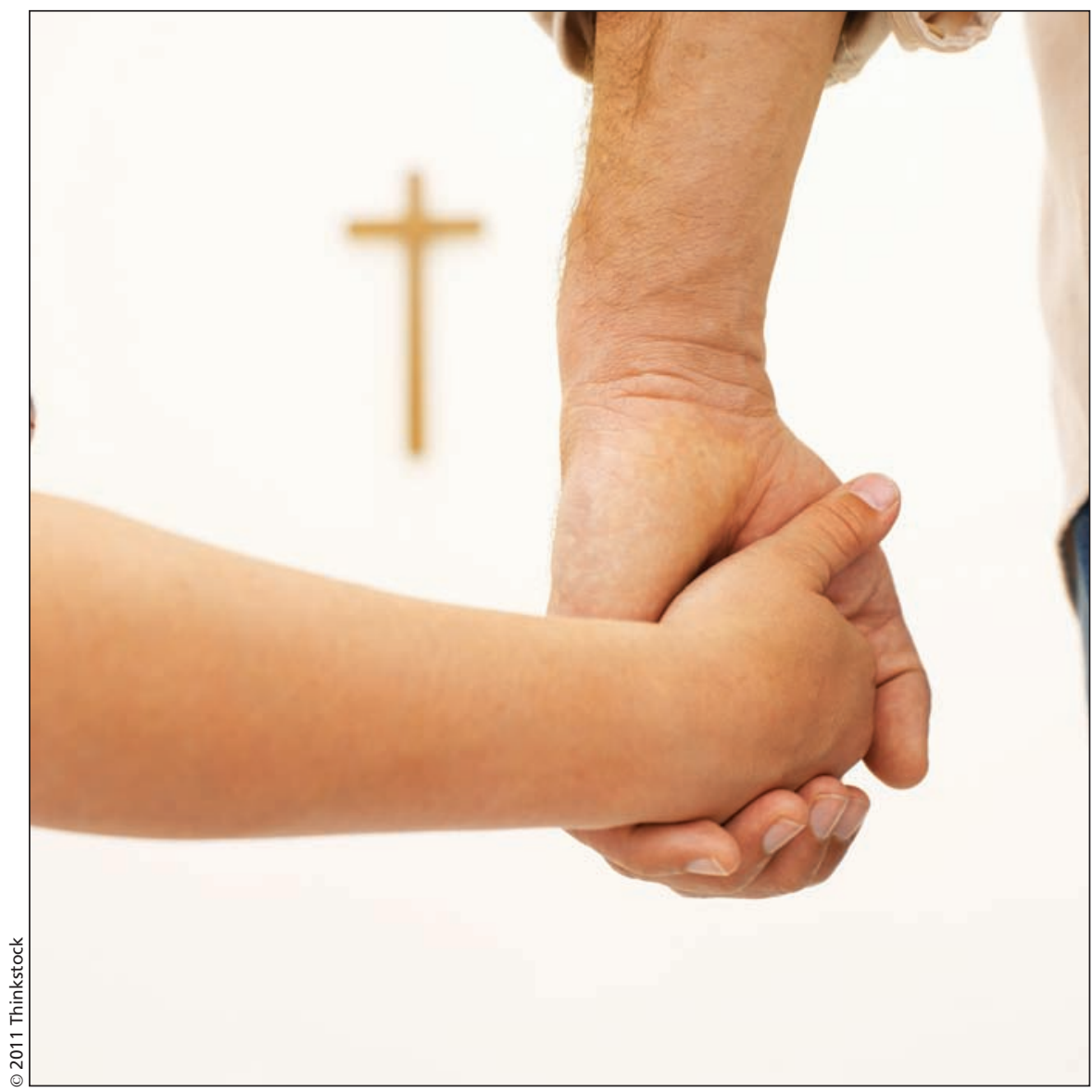

Parents belonging to religious sects that shun medical care put their children's health at risk when they rely on faith alone to address treatable conditions, say advocates for children's medical rights.

to approve blood transfusions, the deaths often occur during the time it takes doctors to prove to the courts that transfusions are medically necessary.

Still, despite the leniency toward faith healing shown by US courts, the number of children dying from medical neglect because of religious beliefs appears to be "going down gradually," says Asser. This is partly due to Children's Healthcare is a Legal Duty (CHILD), an organization that lobbies states to repeal protections in criminal codes that implicitly condone faith healing.

In May, Oregon's senate passed a law repealing exemptions in its criminal code that allowed faith healing to be used as a defence in crimes such as homicide and neglect.

John Clague, a spokesman for the Christian Science church in Oregon, said he supported the new law because of the high number of child deaths in the Followers of Christ Church. When asked about the 28 deceased Christian Science children in the Pediatrics investigation, he lamented their deaths, saying that "unlike some other churches, we don't say these deaths are God's will." He claimed his church leaders expect their followers to seek medical care for their children when faith healing "isn't working" or in situations where a child may die for lack of care. 
But the Christian Science church "continues to support religious accommodations for the responsible practice of spiritual healing," says Adam Scherr, the church's national media coordinator.

None of the parents implicated in recent Followers of Christ Church faith healing deaths in Oregon were reachable for comment and defence attorneys for the Wylands did not respond to repeated phone messages. However, a man who answered the phone at the Followers of Christ Church in Oregon City said he staunchly believed faith healing works, in part because "my mother is going on 95 and my grandparents lived well into their eighties."

While arguing deaths of children in his community were "the divine will of God" and saying "one just died the other day, from sepsis, I think," the man, who refused to give his name, also wanted to make it clear that his church does not force parents to avoid doctors. "That's up to them if they want to take their children to a doctor."

But some leaders of religious sects tend to have different messaging for the general public than for members, according to CHILD founder Rita Swan, who lost her 16-month-old son to spinal meningitis in 1977 after being pressured by fellow members of a Christian Science church to eschew medical care for faith. Horror stories are often spread about medical treatment, she says, while faith healing miracles receive much attention.

Given this context, lawmakers in favour of religious defences argue that parents making what they believe are the best decisions for their children's health shouldn't be treated as criminals. Swan argues, however, that when criminal laws apply to everyone equally, parents in churches practising faith healing have an "excuse" to visit doctors. "If the law plainly tells them that they must get children to a doctor, I think that's much easier, and on one level they're relieved," says Swan.

According to Dr. Jim Lace, an Oregon pediatrician who lobbied against legal exemptions for faith healing, medical neglect is more likely to be reported when there are no religious exceptions. Some citizens erroneously think that child protection services can't intervene in faith healing cases because of "confusion around the laws," he says.

Likewise, Asser argues that faith healing parents should be treated the same way as anyone else who neglects a child. "If you or I get drunk and pass out and a child dies as a result, we go to jail, but if a child dies of a preventable medical issue because of these parents' own form of being stoned on religion, they're not held liable." - Wendy Glauser, Toronto, Ont.

CMAJ 2011. DOI:10.1503/cmaj.109-3944 